\title{
Retrodental synovial cyst: MRI findings
}

\author{
Duzgun Yildirim, ${ }^{1}$ Burcin Tutar, ${ }^{2}$ Ahmet Bas, ${ }^{3}$ Onur Tutar ${ }^{3}$
}

${ }^{1}$ Department of Radiology, Iskenderun Military Hospital, Hatay, Turkey

${ }^{2}$ Department of Radiology, Mamomed Radiology

Laboratory, Istanbul, Turkey ${ }^{3}$ Department of Radiology, Istanbul University Cerrahpasa Medical Faculty, Istanbul, Turkey

\section{Correspondence to}

Dr Ahmet Bas,

dr.ahmetbas@hotmail.com

\section{DESCRIPTION}

Synovial cysts of the cervical spine are extremely rare. We describe a case concerning a 57-year-old woman who presented with uncertain cause of odontoid fracture, resulting in a cystic lesion compressing the upper cervical spinal cord. She had a history of neck pain and she had no history of head and neck trauma. There was no neurological deficit and no hyper-reflexia. Laboratory studies (including RA factor) were normal. Minimal invasive surgery of $\mathrm{C} 1 / \mathrm{C} 2$ transarticular fusion was successfully performed. The patient was allowed to walk within 9 days after surgery.

After surgery, although significant improvement in pain and disability occurred, MRI showed an ovalshaped lesion, posterior to the odontoid process, causing slight compression of the spinal cord. This mass was characterised by a low signal intensity on T1-weighted images and high signal intensity on T2-weighted images (figures 1 and 2). The most useful method for diagnosis was MRI.

Many theories have been proposed to explain what causes spinal synovial cysts. ${ }^{12}$ Synovial cysts generally arise at the facet joint capsule. ${ }^{2}$ The atlantoaxial instability was so severe; therefore, stress at the C1C2 facet joints might have produced the synovial cyst.

Synovial cysts as a result of spinal fracture are most common in the lumbar region, followed by the thoracic and then cervical region; cervical cysts are rare, ${ }^{3}$ but they should be considered in the differential diagnosis of an extradural mass of the upper cervical spine.

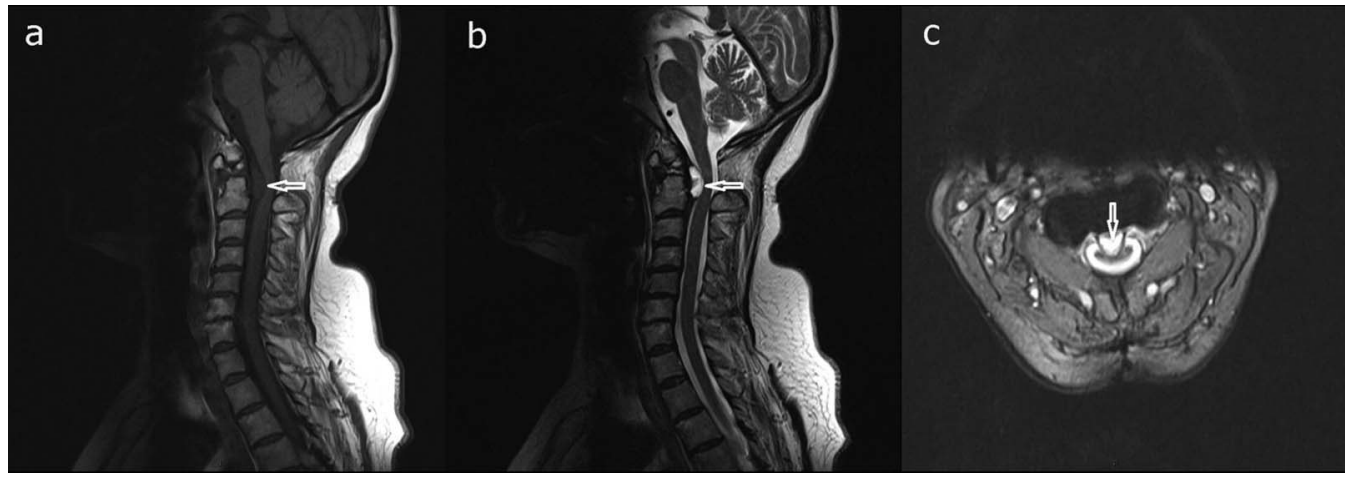

Figure 1 MRI demonstrating an oval-shaped cystic lesion at the anterior of the spinal canal at the atlanto-axial junction (white arrow): (A) sagittal T1-weighted image precontrast, (B) sagittal T2-weighted image and (C) axial fat saturated T2-weighted image.

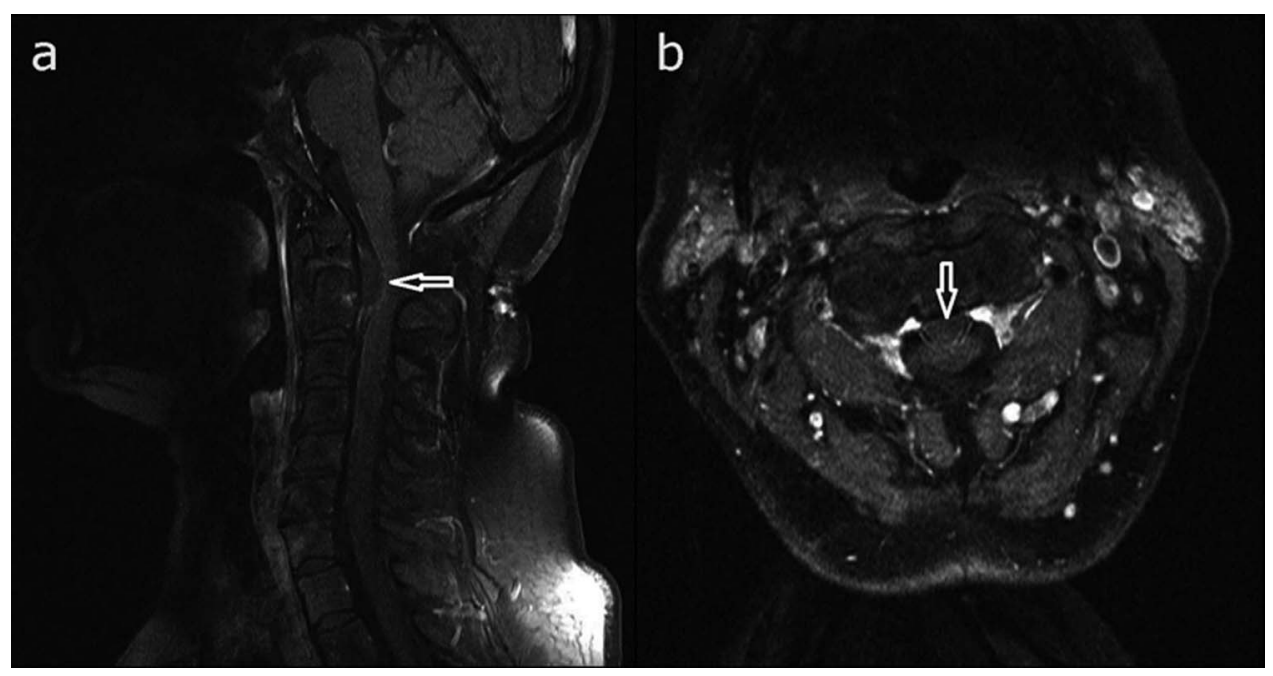

Figure 2 Postcontrast fat saturated T1-weighted MRI showing a hypointense signal of the cyst (white arrow): (A) sagittal and (B) axial. 


\section{Learning points}

- Synovial cysts of the cervical spine are extremely rare.

- Degenerative intraspinal cysts may cause various neurological symptoms.

- These degenerative intraspinal cysts of the spine are usually diagnosed by MRI.

Contributors $D Y$ and $A B$ have made substantial contributions to the acquisition of the clinical data and analysis of the previous reports in the literature. BT and OT were involved in drafting this manuscript. All authors read and approved the final manuscript.
Competing interests None.

Patient consent Obtained.

Provenance and peer review Not commissioned; externally peer reviewed.

\section{REFERENCES}

1 Onofrio BM, Mih AD. Synovial cysts of the spine. Neurosurg 1988;22:642-7.

2 Patel SC, Sanders WP. Synovial cyst of the cervical spine: case report and review of the literature. Am J Neuroradiol 1988;9:602-3.

3 Parks RM, König MA, Bosczyk B, et al. Transarticular fusion for treatment of cystic lesion arising from an odontoid fracture. Eur Spine J 2013;22:21-5.

Copyright 2013 BMJ Publishing Group. All rights reserved. For permission to reuse any of this content visit http://group.bmj.com/group/rights-licensing/permissions.

BMJ Case Report Fellows may re-use this article for personal use and teaching without any further permission.

Become a Fellow of BMJ Case Reports today and you can:

- Submit as many cases as you like

- Enjoy fast sympathetic peer review and rapid publication of accepted articles

- Access all the published articles

- Re-use any of the published material for personal use and teaching without further permission

For information on Institutional Fellowships contact consortiasales@bmjgroup.com

Visit casereports.bmj.com for more articles like this and to become a Fellow 